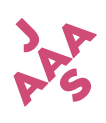

Reviews

case of the United States, ecocritical work in African American studies, e.g. by Paul Outka, and postcolonial ecocriticism could be suggestive in this regard. In the same vein, American conceptions of itself as "Nature's Nation" (Perry Miller) and related cultural myths, which keep informing America's imagined relation to the environment (as explored by David Nye and others), might have complicated the cognitive argument. Linking cognitive and contextual approaches might create new theoretical ground for future ecocritical work in literary and cultural studies. Alexa Weik von Mossner's study will certainly be an important cornerstone for such future scholarship.

\title{
A Book of American Martyrs. By Joyce Carol Oates (London: Fourth Estate, 2017), 736pp.
}

Johannes Mahlknecht, University of Innsbruck DOI: 10.47060/jaaas.Viil.88

With A Book of American Martyrs, Joyce Carol Oates's latest novel, the author tackles one of America's most dividing issues head-on: abortion, and with it the morality behind the opposing ideals of "pro-life" and "pro-choice." With much feeling and, it seems, no mercy, Oates pits representatives of either conviction against one another, as well as against themselves-their anger, grief, frustration, and their faith. That the novel, in its more than 700 pages, allows us to examine our own convictions-or what we think are our convictions-about the (im)morality of legalized abortion, ends up being only one of its merits.

In some detail, Oates traces the lives of two families in the aftermath of the key event that ties them together: the murder of abortion doctor Gus Voorhees and his bodyguard at the hands of the religiously motivated pro-life activist Luther Dunphy. Is it possible, the novel asks, to lament the deeds of either party (killing unborn babies vs. killing "baby killers") and yet admire both characters, Voorhees and Dunphy, not for what they did but for why they did it? For the personal sacrifices they made in order to do what they both believed to be their duty? Is it cynical to call both Vorhees and Dunphy "martyrs" (which the novel does, or appears to do), or is that exactly what they both are? Voorhees, who keeps providing abortions to desperate women despite the increasingly violent protests by religious activists, staying true to his unshakeable conviction that a woman must be granted control over her own body no matter what. And Dunphy, who knowingly risks the death penalty for his belief in defending the right to life of unborn children, even if that means destroying the life of others.

Although the plot spirals around these questions by tracing the events in the years following the murder, it is not Voorhees and Dunphy who are the protagonists 
of the book, but the families having to live through the aftermath of the killing. In particular, the novel ends up focusing on the daughters of either men; the liberal, sophisticated Naomi Voorhees in one corner, and the fiery, underpriviledged Dawn Dunphy in the other, their fates tied together by their grief over the violent deaths of their fathers (the murder of Vorhees and the execution of Dunphy), and by their respective attempts at dealing with it.

Difficult material, then, and no less so because it often seems that, even after the killing, Oates heaps tragedy upon tragedy, particularly for the Dunphy family, who face-or refuse to face-calamities such as impending financial ruin, drug dependency, and sexual assault. Moments of relief, for all of the characters that populate the book, are few and far between. Naomi, in her attempts to heal, becomes obsessed with gathering material about her father's life and death in order to build a giant archive. (This, conveniently, serves as a literary device that allows us to hear throughout the novel a multitude of different voices interviewed about their personal connections to the murders.) And while witnessing Naomi's struggles to lead a normal life and to bridge the widening chasm between herself and the remainder of her family is never less than interesting, it pales in comparison to Dawn's story. Channeling all her pent-up rage and longing for religious fulfillment into a boxing career, her gradual rise to (near-)stardom outlined in the later chapters of the book is so breathlessly told that it seems like a little novel in its own right. Abandoned is the otherwise all-pervading subject of the book-abortion-in favor of a thrilling, lengthy excursion into the visceral world of female boxing. Here Oates's storytelling bravado more than compensates for what certainly feels like a temporary loss of thematic focus.

And when the threads finally do come together in the end, the result feels true. There are no easy answers for any of the characters, nor for the reader, in A Book of American Martyrs, but despite all the anguish and heartbreak the novel is, ultimately, not a book about grief but a book about overcoming grief, and about the many steps it takes to get there-however clumsy, painful, and arduous they may be. A challenging, exhausting, but also a very much rewarding experience. 